\title{
Stakeholders and Long-Term Sustainability of SMEs. Who Really Matters in Crisis Contexts, and When
}

\author{
Montserrat Manzaneque-Lizano ${ }^{1}\left(\mathbb{D}\right.$, Esteban Alfaro-Cortés ${ }^{2, *}{ }^{-}$and \\ Alba María Priego de la Cruz ${ }^{3}$ (D) \\ 1 Department of Business Administration, External and Internal Information Systems of Organizations: \\ Corporate and Management Information (GISEIO), Castilla-La Mancha University, 16071 Cuenca, Spain; \\ Montserrat.MLizano@uclm.es \\ 2 Faculty of Economics and Business, Quantitative Methods and Socio-economic Development Group, \\ Institute for Regional Development (IDR), Castilla-La Mancha University, Plaza de la Universidad, 1, \\ 02071 Albacete, Spain \\ 3 Department of Financial Economics, Accounting and Operations Management, Huelva University, \\ 21002 Huelva, Spain; alba.priego@decd.uhu.es \\ * Correspondence: esteban.alfaro@uclm.es
}

Received: 8 October 2019; Accepted: 6 November 2019; Published: 20 November 2019

\begin{abstract}
The impact of crises on the long-term sustainability of small and medium-sized enterprises (SMEs) has been attracting growing interest in the literature and from governments due to the significance of such companies with respect to economic growth, innovation, and employment. Although failure prediction models have been proposed based on accounting and other qualitative information, little is known regarding the influence of stakeholders on the failure process of SMEs. From the perspective of long-term sustainability, this article analyzes the role of the financial influence of stakeholders on the likelihood of business failure. An empirical study was carried out on a sample of 2352 Spanish SMEs, examining the differences between failed and non-failed SMEs and using a classification tree methodology to investigate the role played by each type of stakeholder in overcoming crisis events. The study provides empirical evidence regarding the relative importance of stakeholders to SMEs under conditions of financial distress, and proposes their categorization on the basis of their control over firms' financial resources. Specifically, the analysis reveals that the capacity of the firm to generate sustainable wealth over time and to overcome critical situations is dependent on the most critical stakeholders. Workers, customers, and suppliers are the most important in ensuring the long-term sustainability of SMEs during the first stages of a crisis. Following the initial operational problems, other creditors (financial institutions) become relevant. In this sense, the results of this study encourage firms and governments to develop cooperation strategies with stakeholders (co-responsibility) in line with the proposed conceptual models of business sustainability.
\end{abstract}

Keywords: small and medium-sized enterprises; stakeholder; business failure prediction; classification trees

\section{Introduction}

According to the traditional view of a firm, the first aim is to maximize profits. However, scholars have recently encouraged the development of new business models based on the approach of "business sustainability". Under this view, firms are part of natural and social systems [1], and sustainability must be understood as a driving force for decision-making [2]. There is growing interest in the field in developing an understanding of the sustainability of small and medium-sized enterprises (SMEs). Although studies have made significant contributions to our understanding of how and why organizations engage in sustainability practices from environmental and social points of view [2], 
other studies have suggested that attention must also be paid to the SMEs' relationships with their stakeholders as potential drivers of sustainability [3,4]. In this sense, sustainability is defined as the "capability of an organization to continue its activities indefinitely, having taken due account of their impact on natural, social and human capitals" [5] (p. 94). In this respect, Post, Preston, and Sachs [6] (p. 9) emphasize that "the capacity of a firm to generate sustainable wealth over time, and hence its long-term value, is determined by its relationships with critical stakeholders." In this sense, the sustainability approach provides the broadest view of the need to define common pathways among stakeholders to achieve greater collaboration and shared satisfaction [4]. One of the most recent contributions in this area is research investigating the viable systems approach (VSA) [7]. According to the VSA, any entity organized with the objective of surviving over time can be considered to be a system and can be analyzed based on the premises of the VSA. As pointed out by Caputo, Buhnova, and Walletzky [4], from the VSA perspective, the challenges of the sustainability approach must be faced by taking all of the actors into consideration (stakeholders) and the value of their possible contributions. Following this line of thinking, existing research has noted that individual-level actions can have an impact on a company's capability to enhance its practices on a collective-organizational level [8]. Accordingly, we followed this line of thinking by highlighting that the individual interests of stakeholders determine the long-term sustainability of the firm. Hence, assuming that the sustainable development concept involves relationships with critical stakeholders, this study responds to other works calling for the development of a "body of knowledge" on "business sustainability" by providing empirical evidence for the dynamic nature of the relationships within the organization, on the basis of which individual actions are able to enhance the long-term sustainability of the firm. This is useful in terms of helping to guide the behavior and strategies of an organization [9].

Consequently, our understanding of the factors that allow SMEs to overcome critical situations is an ongoing concern in business research, and is key to making sound corporate policy decisions from a sustainability perspective. It has been empirically demonstrated that SMEs have a lower probability of survival than larger firms [10]. Indeed, the high rates of business failure suffered by SMEs across economies [11] during the last global economic and financial crisis highlights the importance of the problem. This problem becomes even more marked if we take into consideration the fact that SMEs represent a significant proportion of businesses around the world. Moreover, they are key to the development and stability of their countries, since they play important roles in economic growth, innovation, employment, and social integration [12]. Mitroff, Pearson, and Harrington [13] emphasized the consequences of the failure of SMEs on stakeholders such as consumers, employees, local communities, the environment, and financial entities.

To address the issue of the long-term sustainability of SMEs, researchers have analyzed factors influencing their failure. Most of this literature attributes the failure of SMEs to internal economic and financial factors [14-16], a lack of quality human capital [17-19], the influence of environmental conditions [20,21], or poor management decisions [22], amongst others. However, in an attempt to explain the risk of failure in SMEs, more recent literature has suggested that individual-level actions can have an impact on collective outcomes [8], given that the firm is part of a system [4,7]. Hence, the SMEs' relationships with stakeholders may affect their long-term sustainability [23]. On one hand, as numerous studies have discussed, SMEs face greater barriers to survival and growth in critical situations, posed by challenges relating to access to financing [24], the availability of skilled staff or experienced managers, competition, production costs, regulations concerning customers [12], inadequate human capital development in terms of training and skills [25], insufficient knowledge to enter international markets [26], and information access problems, all of which mean that stakeholders play a vital role in securing resources that are essential for the firm's survival. Furthermore, in terms of organizational structures and management styles, SMEs tend to be characterized by having far less control over their environment [27], negotiating power [28], and political influence [29] than large and multinational corporations. Consequently, they are exposed to greater risk stemming from uncertainty about the environment, and are significantly dependent on their stakeholders' attitudes and behavior. 
On the other hand, compared to large firms, SMEs appear to have a different approach to managing stakeholder relationships, engaging with them on a more informal, intuitive, and personal basis [30]. In fact, the literature highlights the important role played by management/owners of SMEs in making day-to-day decisions and managing relationships with other stakeholders by creating common goals and motivations [8].

Although there has been some discussion in the literature of stakeholder behavior in SMEs [23,30], to our knowledge, little has been done to empirically analyze the stakeholders' effect on the likelihood of firm distress in SMEs [31]. A more in-depth understanding of stakeholder impact on business outcomes will help connect the growing body of stakeholder theory and VSA research focusing on business sustainability. As Caputo, Buhnova, and Walletzky [4] point out, a sustainability approach requires taking into consideration all of the actors (stakeholders) and valuing their possible contributions. In particular, in crisis situations, individual-level actions can influence collective outcomes. Therefore, as Pajunen [31] (p. 1262) asserts, in such situations, the "primary concern is to define the stakeholders that have influence on the organization's survival." Consequently, a greater understanding of this issue is required; this study is an attempt to fill this important gap in the literature.

Moreover, when analyzing business failure, previous research has been focused on identifying variables that allow firms to be classified as either healthy or in financial distress, at various specific points in time (one, two, or three years before failure) [32,33]. In this respect, recent studies do not consider business failure as occurring at a single point in time; rather they distinguish between different processes of failure [34-39]. Despite the contribution of these studies to a longer-term perspective of the business failure process, most of them have focused on validating the seminal model of business failure prediction. Thus, there are no previous empirical studies that provide evidence regarding stakeholder influence on the long-term sustainability of a business. This study focuses on which stakeholders influence the outcome of crisis situations in SMEs as well as how and when they do so.

To shed light on this topic, our study addressed the following research questions: Which are the most relevant SME stakeholders in order to successfully overcome a critical situation? At what point in the business failure process does each SME stakeholder affect the outcomes? This study attempts to answer these questions by means of an empirical analysis using a sample of 2352 Spanish SMEs. Given that accounting data from the firm's annual report reflect the economic and financial relationship between the firm and its stakeholders, we assume that these data are an indicator of the stakeholders' influence on the firm. We empirically assessed which stakeholders have an impact on the likelihood of SME failure and at what point they have the greatest impact on business outcomes.

This study offers a number of relevant contributions to the literature on SME business failure and business sustainability. First, it adds to the VSA approach to sustainability by providing evidence that stakeholder actions at the individual level have an impact on collective outcomes. Thus, under this approach, the firm should be considered as a system with dynamic relationships among numerous different actors, requiring new tools to manage and create pathways that can align their individual expectations and needs in order to achieve collective long-term sustainability. Second, this study adds to the existing research on business failure prediction through its specific focus on the stakeholders' influence on the business. By combining stakeholder theory and the resource-based view, this paper identifies the key stakeholders in SME distress situations, on the basis of their control over crucial economic and financial resources. Accordingly, this paper examines stakeholder behavior as a critical factor in the SMEs' ability to overcome financial distress. As far as we are aware, this is the first such study on this topic. Furthermore, the empirical analysis indicates the need for a new corporate governance landscape based on the establishment of sound relationships with critical stakeholders, who are key to achieving long-term sustainability.

Third, since conflicts of interests between different stakeholders are likely to intensify when the firm is facing a crisis, we propose a categorization of key stakeholders according to their contribution to overcoming the crisis and ensuring the long-term sustainability of the firm. To the best of our knowledge, previous literature [40] has drawn on theoretical and historical arguments to propose 
categorizations of stakeholder influence on organizational survival. In this study, we applied empirical methods that provide support for the theoretical postulates.

Fourth, according to Mitchell, Agle, and Wood [41], the importance of stakeholders is relative and can change over time. Our research empirically tested this assertion by showing that the role played by stakeholders in a SME's crisis situation and in ensuring long-term sustainability changes over time. The findings highlight the different impacts of stakeholders at different points along the trajectory of decline. This provides a useful heuristic for considering when each stakeholder group influences the likelihood of firm survival, and lends support to other studies that claim that business failure is a process, and not a state. Thus, using the CART (classification and regression tree) algorithm, a non-parametric classification technique based on pattern recognition, we propose a categorization of stakeholders for use in financial crises, by identifying the order in which, and the moment at which, they influence the outcomes of SMEs. In fact, according to Pearson and Clair [42] and Ulmer [43], the success of crisis preparation depends on the ability of the firm to understand the behavior of its stakeholders under crisis conditions.

In order to achieve the research aims, the rest of the paper is organized as follows. Section 2 develops the hypotheses and discusses the related literature on the stakeholders' impact on the likelihood of business failure. Section 3 sets out the methodology used and presents the results of our empirical application, along with robustness checks for the models proposed. Finally, Section 4 presents a discussion of the results and draws some conclusions.

\section{Background and Hypotheses}

\subsection{Stakeholders and the Likelihood of SME Failure}

According to the assumptions of stakeholder theory and under a business sustainability perspective [44], the firm is a system whose survival depends on its surroundings [4,7]. The purpose of the firm is not only to create and distribute value between the shareholders, as agency theory posits, but also to provide value to other stakeholders and generate sustainable wealth over time. As collaboration between stakeholders contributes to creating added value, and value creation plays a part in the firm's long-term survival, stakeholders are essential for the sustainability of the firm. Following this line of thinking, different stakeholder definitions and categorizations have been presented in [45], which contribute to the construction of a stakeholder theory framework. As indicated by Post, Preston, and Sachs [6] (pp. 8,9) "the capacity of a firm to generate sustainable wealth over time, and hence its long-term value, is determined by its relationships with critical stakeholders". In this sense, firms that are able to collaborate with stakeholders and incorporate their interests in their product, services, and processes may be able to increase firm revenue [46], and, therefore, improve firm performance and the chances of long-term survival.

Accordingly, Becchetti, Cicirettim Hasan, and Kobeissi [47] argued that firms should focus on key financial and nonfinancial stakeholder interests because they affect the firms' ability to generate and capture value. In this regard, Pereira and Rossetto [48] showed a positive relationship between the capability to manage stakeholder demands and the firm's economic and financial performance.

This rationale is clearly relevant in crisis situations, where different stakeholder demands come into conflict, and they begin to form alliances. Thus, some of the decisions taken by managers in these contexts may satisfy only one group, rather than the stakeholders as a whole [49]. If stakeholders are unwilling to cooperate, this exacerbates the firm's difficulties and limits its ability to overcome crisis situations [40]. For this reason, and in an attempt to help prevent business failure, researchers have long been interested in understanding how stakeholders influence firm outcomes.

The existing research on stakeholder impact on firms' decisions focuses on large and multinational corporations [50]. However, as stated above, SMEs have specific attributes that distinguish them from large and multinational firms $[23,24]$, thus influencing their relationship with stakeholders and making them more dependent on outside assistance [51]. Given the lack of critical resources within SMEs [52], 
they are more dependent on external resources than their larger counterparts. Decision-makers in SMEs should therefore be more concerned about the stakeholders' influence on the firm, as they can help to reduce the uncertainty inherent in an impending crisis.

Although some studies have focused on factors leading to firm distress in SMEs [21], exactly how the stakeholders affect business distress is a question that remains largely unexplored by the academic community. In order to provide a better understanding of this issue, we combined stakeholder theory and the resource-based view, arguing that, when faced with an impending crisis, having control over certain financial resources gives some stakeholders relative power over the future of the business. Assuming that stakeholders influence the outcome of a crisis, we propose a categorization of stakeholders based on their influence on a SMEs' financial distress during a crisis. We then formulated and tested a number of hypotheses.

\subsubsection{Shareholders and SMEs' Financial Distress Likelihood}

When a firm's performance goes into decline, the availability of financial resources is key to implementing strategies to overcome the external shocks that could jeopardize the future survival of the firm [53]. To avoid further negative consequences, the firm needs access to financial support that will help it overcome situations of financial vulnerability. Previous literature has found that there is a gap in the capital market, which denies the SMEs' access to public debt (long-term debt) and equity [54]. According to the pecking order theory of finance [55], in the domain of losses, SMEs use informal sources of financing such as family and friends, or internally-generated funds in the form of retained earnings, before turning to external sources. This prioritization by SMEs is driven more by necessity than by choice. That is, certain characteristics of SMEs such as informational opacity [56] make them heavily dependent on internal sources of funding because their risk of loan default is greater.

The problem of SMEs' access to external funds becomes more evident when firms begin to experience financial or economic difficulties. Lenders often restrict credit to such businesses and/or tighten credit conditions [57], making it even more difficult to access new funds or repay debt, consequently increasing the risk of failure. Therefore, it is expected that higher levels of internally-accumulated financial resources (slacks), positively impact the firms' financial autonomy and their ability to develop new projects to overcome a slowdown. Slacks are defined by Bourgeois [58] (p. 30) as a "cushion of actual or potential resources which allows an organization to adapt successfully to internal pressures for adjustment or to external pressures for change in policy, as well as to initiate changes in practice with respect to the external environment." In SMEs, slacks act as a buffer against failure and help to ensure the long-term survival of the firm [59].

In other words, financial support from a firm's shareholders is reflected in its equity, which includes not only share capital, but also retained earnings and current earnings. Previous literature on SME financing shows that when faced with a lack of alternative financial sources, SMEs seek financing through equity capital [60]. When SMEs suffer a decline in performance, lenders could restrict the firm's access to external financing. Under such circumstances, slacks or available internal funds, improve the firm's ability to pay off lenders (banks, suppliers, creditors) and strengthen the firm's ability to look for alternative sources of funds. In addition, when SMEs have a surplus of resources, this bolsters their bargaining position against adverse stakeholders and allows them to gain an advantage in negotiations (for example, with the labor force or suppliers). Thus, slacks are essential for overcoming situations of financial vulnerability.

Taking into account these arguments, we posit that firms with more internal funds (slacks) are better able to ensure their long-term survival and reduce the likelihood of financial distress. Thus, we hypothesize the following:

Hypothesis 1 (H1): Shareholders' financial resources have a negative influence on the likelihood of financial distress. 


\subsubsection{Lenders and SMEs' Financial Distress Likelihood}

It has also been argued that the main cause of SME failure is liquidity issues [61]. However, as additional equity could be associated with a dilution of ownership and control, SMEs' owner-managers may prefer debt financing to new equity. The survival of small firms thus heavily depends on the effective financial support of external creditors. For example, Wruck [62] found evidence that lenders play a key role in the firms' financial restructuring processes. Nevertheless, in the situation in question - that is, when firms are experiencing financial distress-another important obstacle arises with respect to securing funds to overcome financial vulnerability. New external financing is often difficult to access and usually offered at a high cost [63], which may make the situation unmanageable for SMEs, as above-mentioned. Due to their lack of access to public debt and equity markets, SMEs tend to use more bank debt [54]. However, according to the related literature, the informational opacity of SMEs [56] is usually associated with more debt-related agency problems [64] and, consequently, with a greater likelihood of being subject to financial restrictions [65] and tighter credit conditions [57]. As a result, the firm could incur excessive refinancing costs, making it difficult to restructure the firm's debt and increasing its risk of failure [57]. This is particularly relevant in Spain because the Spanish financial system is largely banking-oriented, with banks being the main long-term financial agent for SMEs [66].

Accordingly, we tested the following hypothesis:

Hypothesis 2 (H2): Lenders' financial resources play a significant role in increasing the likelihood of financial distress.

\subsubsection{Workers and SMEs' Financial Distress Likelihood}

The relationship between a firm and its workers is another factor that has been shown to exert an effect on the likelihood of business failure. That is to say, the relative importance of workers in an SME's production system could affect the progression of the crisis in a number of different ways. First, an effective and efficient workforce could make a crucial difference by enabling the firm to take steps toward improving its performance and solving its economic problems. In fact, previous literature has highlighted the importance of the management of workers in the survival of SMEs [67]. Second, the firm's ability to recover from financial distress depends on, among other things, the labor cost of firm restructuring, the size of the workforce, and workers' willingness to make financial concessions [68].

Third, SMEs stand to benefit if workers accept the implementation of flexible working practices essential to firm survival [69]. As the creation and maintenance of good relations with employees constitutes a unique, inimitable, and vital corporate resource [70], those good relationships represent a dynamic capability [71] and a substantial competitive advantage over competitors [72]. In addition, in their role as a critical corporate resource, workers could help solve or prevent possible business failure scenarios by improving the company's reputation [73] and its ability to increase its market share. Likewise, cultivating good relationships with employees may make it easier to retain skilled workers who improve productivity, and help prevent certain employee actions (strikes, boycotts, etc.), which can negatively affect the company's position in the market and, therefore, its profitability [72]. In addition, SME workers tend to strongly identify with the owners' aspirations and ambitions. All of these factors could facilitate restructuring. In light of these different arguments, we hypothesize that better-paid employees play a greater role in reducing the likelihood of SME failure:

Hypothesis 3 (H3): Workers' salaries as a distribution of the firm's financial resources play a significant role in reducing the likelihood of financial distress.

\subsubsection{Customers and SMEs' Financial Distress Likelihood}

Customers could also influence the economic and financial situation of SMEs in crisis conditions; however, there is conflicting evidence in this respect. First, if customers perceive that the company 
is in trouble, they may look for alternative firms that meet their needs, especially for products that require after-sale services or an advance payment for the product or service [63]. A firm's commercial dependency on customers has also been suggested as a factor that increases the risk levels of SMEs [74]. As maintaining cash flow is critical in the early stages of a financial crisis, the external dependence of debtors is essential to the SMEs' survival [75]. Conversely, other studies have shown that offering higher levels of credit to customers increases firm value and improves performance. A number of studies empirically support this assertion. Kestens, van Cauwenberge, and Bauwhede [76], analyzed a sample of Belgian firms and found that during the 2008 financial crisis, companies that increased their trade receivables achieved higher levels of profitability during the crisis. In Spain, the results of the study by Martínez-Sola, García-Teruel, and Martínez-Solano [77] showed a positive relationship between investment in credit to customers and firm profitability. Accordingly, trade credits are considered as a channel for penetrating highly-competitive markets, especially during financial crises.

Therefore, we propose the following hypothesis:

Hypothesis 4 (H4): Customers' financial resources play a significant role in reducing the likelihood of financial distress.

\subsubsection{Suppliers and SMEs' Financial Distress Likelihood}

In the short term, financial frictions in SMEs are usually related to trade debt [78]. As stated above, banks are usually more reluctant to offer debt to SMEs, or they demand high interest rates in return. Thus, for SMEs, the cost of debt usually exceeds the effective cost of trade debt. In this regard, suppliers of SMEs could also influence the likelihood of financial distress. According to Bowen, Daley, and Huber [79], when a firm is in financial distress, suppliers tend to be less cooperative than when it is healthy; they may even demand prepayment for delivering their usual supply. Suppliers could thus generate operational and financial conflicts in the firm's operational supply phase. Similarly, Chatterjee, Dhillon, and Ramirez [49] claimed that this group of creditors was the most difficult to negotiate with, particularly because they knew less about the company than other stakeholders such as workers and financial institutions. All this may adversely affect the possibilities of corporate restructuring.

Accordingly, we propose the following hypotheses:

Hypothesis 5 (H5): Suppliers' financial resources play a significant role in reducing the likelihood of financial distress.

\subsection{Crisis Development and Stakeholders Influence}

As some financial distress researchers have noted, corporate financial distress involves a process rather than occurring at a specific point in time [80]. Over the course of this process, the different levels of risk perceived by stakeholders could be linked to their influence on the risk of distress. Accordingly, the importance of stakeholders is relative and can change over time [41]. In this sense, Altman [81] states that the financial distress process is often slow and usually starts when the return on equity is lower than that obtained with similar investments. When this situation persists over time, companies begin to generate less income than expenditure, leading to negative operating results [82]. Such a situation could be termed as "economic failure" or "gradual decline". According to the competing theory of turnaround [83], small firms are particularly vulnerable in that kind of situation as they usually fail to make effective decisions. Hambrick and D'Aveni [84] attribute this problem to management's inability to react quickly enough to the situation; that is, when company performance changes gradually, "a serious response is never triggered, or at least not until it is too late to respond." (p. 4). When the economic situation remains poor over time or when a firm is unable to adjust its incoming and outgoing cash flows, financial distress can occur [85]. The concept of problem framing requires SME managers to urgently take whatever action is necessary to overcome situations of financial vulnerability and 
focus their attention on the relevant stakeholders to avoid further deterioration in the performance of the firm.

However, according to Mitchell, Agle, and Wood [41], stakeholder salience- that is, the degree to which managers should give priority to competing stakeholders' claims (according to the attributes of power, legitimacy, and urgency)—changes over time. Their study thus calls for research that analyzes the dynamic nature of stakeholder-manager relationships. In line with the arguments set out above, we posit that stakeholder impact on the likelihood of financial distress changes over time. That is, the degree of financial difficulties determines the level of special collaboration required of the stakeholders. Under this rationale, we tested the influence of each group of stakeholders over the four years leading up to business failure to analyze changes in the significant influence of each group over this period. Therefore, we propose the following hypothesis:

Hypothesis 6 (H6): Regarding the likelihood of SME failure, stakeholder salience changes over the period leading up to the financial distress of the firm.

The theoretical model and the proposed hypotheses are presented in Figure 1.

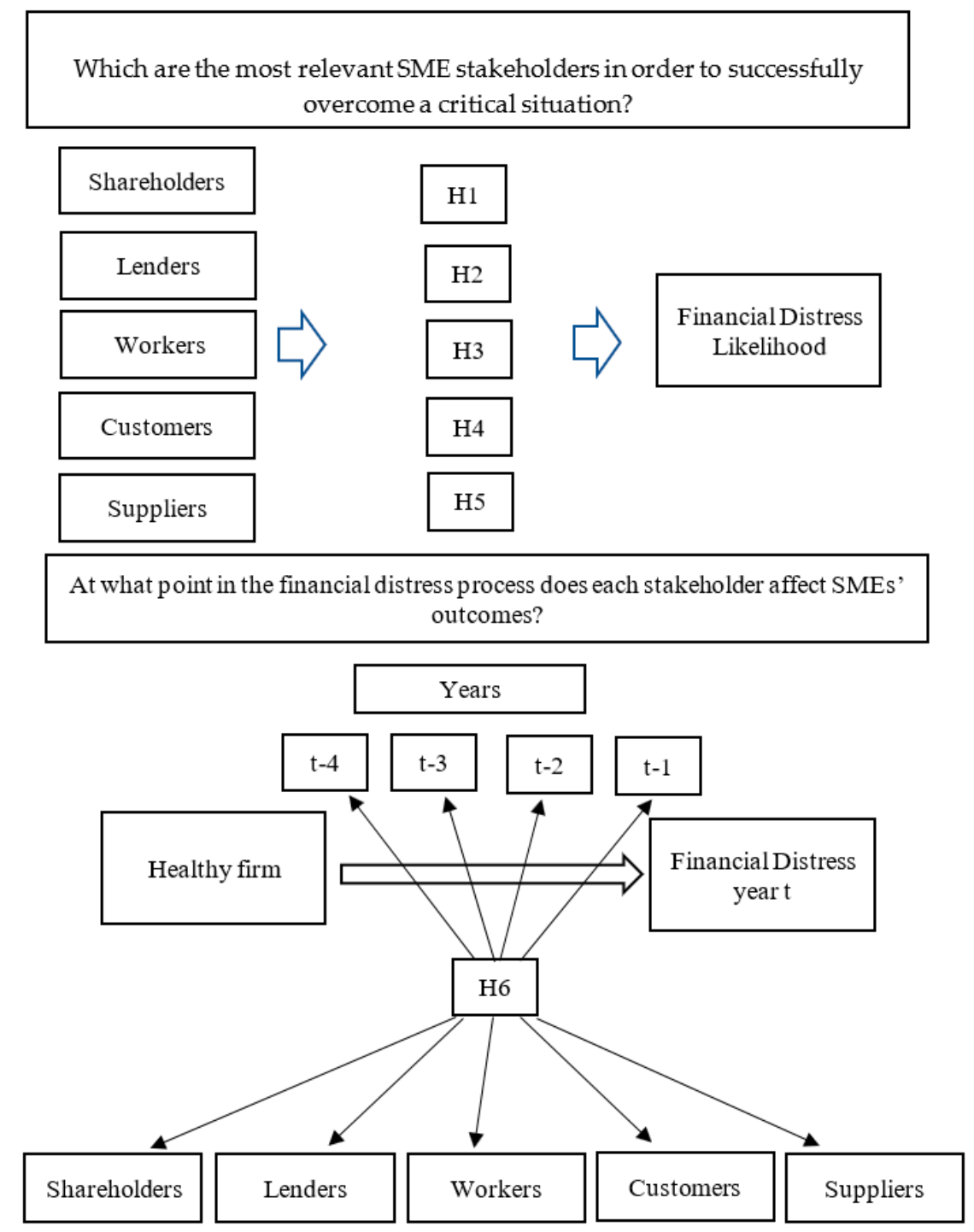

Figure 1. Conceptual model. 


\section{Methodology}

\subsection{Sample}

To construct our sample, we used a matched-pairs design, matching firms on a one-to-one basis. A sample of 2272 failed SMEs was collected from the Iberian balance analysis system (SABI) database of the Bureau Van Dijk (BVD). A firm was defined as failed if it experienced one of the following legal situations in 2010: bankruptcy [86], dissolution, or private settlement agreements [87]. Drawing from prior literature, we matched each distressed firm with a non-distressed or active firm of comparable size (total assets) and from the same industry (based on the 4-digit code in the Spanish National Classification of Economic Activities) to control for the potential effect that industry-specific characteristics may have on the SMEs. After removing all firms with incomplete information or missing data, we obtained a final matched sample of 2352 SMEs. Finally, we used 1568 as a training sample to develop the classification tree (784 failed firms/784 non-failed firms) and the other 784 firms were used to test the predictive ability of the model. Accounting information was taken from the SABI database to calculate the variables representing the stakeholders' control over a firm's resources. The period of analysis covered the four years prior to failure (2010), namely $\mathrm{t}-1, \mathrm{t}-2, \mathrm{t}-3$, and $\mathrm{t}-4$, a commonly-used practice in empirical research into business failure [88]. Finally, we analyzed whether our sample was representative of the Spanish population of SMEs by testing the maximum allowable error for a finite population. The maximum error was $2.47 \%$ with a $95 \%$ confidence level, thus showing that our sample was representative of the population. The distribution of the sample by industry (grouped into three sectors) is shown in Table 1.

Table 1. Sample and variable description.

\begin{tabular}{lcc}
\hline Industry Distribution & $\mathbf{N}$ & $\mathbf{\%}$ \\
\hline 1. Manufacturing & 432 & 27.55 \\
\hline 2. Construction & 356 & 22.70 \\
\hline 3. Services & 780 & 49.75 \\
\hline Total & 1568 & 100.00 \\
\hline
\end{tabular}

\subsection{Description of the Variables}

Eight predictor variables, which represent the stakeholders' control over the firm's financial resources, have been used to proxy stakeholder behavior. The data for these variables have been widely used in previous studies to develop predictive models of business failure [63,89], and were sourced directly from the accounting statements.

Regarding the first hypothesis, we used the variable "Shareholders' financial resources", calculated as the ratio of equity to total debt. This variable captures the impacts of slacks on the likelihood of SMEs' financial distress. Although some studies have used different proxies for slacks (firm size, productivity, equity-to-debt-ratio [90], we followed Sui and Baum [91] in using the equity-to-debt-ratio as proxy for slacks in SMEs.

For lenders, we took two proxy variables that captured the different impact those stakeholders have on the financial health of the SMEs. First, the variable "lenders' financial resources I" measures the proportion of assets funded through debt [34]. As discussed above, it is expected that a higher debt-to-total assets ratio increases the likelihood of financial distress [92]. In this regard, we posit that having fewer assets to use as collateral for loans could be an obstacle to SMEs (who usually find it hard to access credit) overcoming difficult situations. In fact, Steijvers, Voordeckers, and Van [93] showed that tangible assets were generally used as collateral to maintain capital structure, especially in times of financial distress. In addition, SMEs often face higher costs of debt when compared with large firms. As has been argued in the literature, reasons for this include the limited availability of information to evaluate the risk [94] and greater debt-related agency conflicts [95]. To capture that effect, the variable 
"Lenders' financial resources II" was included in our model, calculated as the ratio of a firm's financial expenses to total debt. Based on previous literature, we posit that SMEs that have to pay higher interest rates to lenders face an increased likelihood of failure.

As discussed above, workers are an internal stakeholder that can also play a relevant role in the likelihood of financial distress. Thus, in order to capture the workers' influence on the economic structure of the firm, we used the variable "Workers' salaries as a distribution of financial resources", which is measured by comparing the salary cost per worker to the corresponding mean value for the sector in which the firm operates. Regarding labor costs, Theng and Wang [96] studied a sample of SMEs in Singapore and highlighted the high mortality rate of these firms. The authors showed that one reason for the failure of SMEs may be labor costs; thus they are key factors to analyze due to their impact on financial distress.

In addition, the literature has set out various ways in which customers affect the financial and economic health of the firm. First, providing credit to customers is one approach that firms use to stimulate their sales, particularly if those firms face profitability issues [97]. In order to capture that effect, we used two variables: (1) "Customers' financial resources" is the rate of change in the firm's operating income divided by the average rate of change in operating income for the sector to which the company belongs; and (2) "Customers' financial resources I" is measured as the volume of credit provided to customers as a share of operating income divided by the average for the sector. With the first variable, we captured possible shocks to the firms' sales, which could increase the likelihood of financial distress. With the second variable, we captured the possible boost to sales growth that firms can achieve by extending more credit to their customers. In this case, we expect that higher levels of trade credit reduce the likelihood of business failure. Second, the collection period for credit sales to customers is also used as an indicator of trade credit risk [98]. We expect that longer collection periods are linked to a greater likelihood of SMEs' financial distress.

Finally, suppliers also play an important role in the capital structure of SMEs. García-Teruel and Martínez-Solano [99] reviewed some of the literature on this topic, pointing out several advantages that justify the SMEs' use of trade debt. In this vein, these authors have argued that trade debts are a great way of obtaining funds for firms that have difficulties accessing bank funds. Specifically, trade debts are a key issue for SMEs because they have difficulty in accessing capital markets and thus rely on the support of their suppliers. We used the ratio trade debt to total expenditures on the purchasing of goods as a measure of the funding suppliers provide to the firm. We expect that a greater value of the variable "Suppliers" financial resources" reduces the likelihood of SME financial distress.

Additionally, two control variables have been used. The first is liquidity, which is measured as current assets to current liabilities. This variable is often used in the business failure literature, showing a negative relationship to financial distress [34]. The second is profitability, which is calculated as the ratio of earnings before interest and taxes to total assets. Previous studies have reported a negative and significant effect of this variable on financial distress [30,34].

\subsection{Statistical Analysis and Methodology}

Descriptive statistics have been calculated for our total sample for the period under analysis (the results are available from the authors upon request). A slight increase can be seen in shareholders' financial resources from $\mathrm{t}-4$ to $\mathrm{t}-1$, reflecting the help they provide to SMEs facing a financial distress situation. Regarding lenders, the statistics show that the debt-to-total assets ratio increased from $t-4$ to $\mathrm{t}-1$; this may increase the likelihood of financial distress because firms have difficulty accessing credit. For workers, the results showed that workers' influence on the economic structure increased over the period under study, which might be one of the reasons for SME business failures. With regard to the customers and suppliers, we observed a decreasing trend in the levels of trade credit and an increase in the collection period for credit sales over the analyzed period, thereby increasing the risk of business failure. Finally, regarding the suppliers, the results showed that the ratio of trade debt to total expenditures decreased over the period, resulting in an increased likelihood of SME financial distress. 
Moreover, correlations have been calculated for each year under study (results are available from the authors upon request). We only found moderate levels of correlation between our variables, so multicollinearity does not appear to be a problem in our study.

After checking the normality of variables and homogeneity of variances, the paired sample t-test was used to test the differences between the means of the two groups (see Table 2). Significant differences emerged between failed and non-failed firms with respect to the behavior of some stakeholders. Specifically, Table 2 shows that for the variables shareholders' financial resources, workers' salaries as a distribution of financial resources, customers' financial resources I, customers' financial resources II, liquidity, and profitability, statistically significant differences were found at the $1 \%$ or $5 \%$ level for at least three of the four years considered. Thus, the prediction model shows those variables to be relevant predictors of the likelihood of SME survival.

The classification tree methodology was used to test the proposed hypotheses. In so doing, this methodology also answered the research questions regarding which stakeholders played a role in preventing business distress, and at what point. This is a useful method that shows the point at which each stakeholder influences the business failure process and in which order they do so. The classification tree is a non-linear, non-parametric classification method [100], the structure of which resembles a tree in that it has nodes, branches, and leaves. The initial set is called the "root node." This initial set is recursively split into mutually exclusive subsets or nodes. A test is used on each node to split it, and thereby increase the homogeneity of the different subsets. In binary trees, only two branches can come out of each node. On each split, the variable that achieves the greatest separation among classes is selected. When a stop criterion is met, the majority class is assigned to the example in this node, which is then denoted as a "terminal node" or "leaf."

One of the main advantages of classification trees is that they can be intuitively understood. They can be useful in data exploration, identifying the most important out of a large number of variables. Data cleaning is less important with this method as outliers and missing values do not strongly influence the model. Nor is the type of data a restriction, as this method can manage both quantitative and qualitative information. It is a non-parametric method (i.e., there are no assumptions about the distribution and the structure of the classifier), which is especially important if the variables do not follow a normal distribution or if there is correlation among the variables, as the trees do not notably suffer from multicollinearity.

The tree models were built using the rpart package [101] of the $R$ program [102]. The financial distress dummy variable was used as the response variable and the different ratios representing the stakeholders' behavior were used as explanatory variables. 
Table 2. Difference of means between failed and non-failed firms.

\begin{tabular}{|c|c|c|c|c|c|c|c|c|c|c|c|c|}
\hline \multirow{2}{*}{ Variables ${ }^{(a)}$} & \multicolumn{4}{|c|}{ Failed Firms } & \multicolumn{4}{|c|}{ Non-Failed Firms } & \multicolumn{4}{|c|}{$p$-Value } \\
\hline & $t-4$ & $t-3$ & $t-2$ & $t-1$ & $t-4$ & $t-3$ & $t-2$ & $t-1$ & $t-4$ & $t-3$ & $t-2$ & $t-1$ \\
\hline V1 & 1.09 & 0.79 & 0.77 & 0.84 & 1.15 & 1.29 & 1.57 & 1.52 & 0.85 & $0.00 * * *$ & $0.00 * * *$ & 0.03 ** \\
\hline V2 & 0.09 & 0.07 & 0.07 & 0.11 & 0.05 & 0.07 & 0.09 & 0.07 & $0.05 *$ & 0.84 & 0.79 & 0.55 \\
\hline V3 & 8.18 & 5.98 & 8.07 & 2.77 & 4.92 & 4.00 & 2.76 & 2.41 & $0.08^{*}$ & 0.25 & $0.00^{* * *}$ & 0.71 \\
\hline $\mathrm{V} 4$ & 40.73 & 47.96 & 34.60 & 46.16 & 11.53 & 12.64 & 12.46 & 15.10 & $0.03 * *$ & $0.02 * *$ & $0.00^{* * *}$ & 0.02 ** \\
\hline V5 & 1.27 & 4.01 & 0.77 & 5.73 & 0.57 & 0.64 & -0.21 & -0.15 & $0.05^{*}$ & $0.06^{*}$ & 0.48 & 0.35 \\
\hline V6 & 2.18 & 1.83 & 1.72 & 1.31 & 0.75 & 0.67 & 0.70 & 0.59 & $0.03 * *$ & $0.02 * *$ & $0.06^{*}$ & $0.00^{* * *}$ \\
\hline V7 & 108.54 & 113.24 & 123.87 & 169.62 & 94.20 & 92.76 & 99.98 & 109.12 & $0.05^{* *}$ & $0.00 * * *$ & $0.00^{* * *}$ & $0.00 * * *$ \\
\hline V8 & 1.32 & 2.84 & 1.16 & 1.17 & 1.18 & 2.122 & 0.97 & 1.05 & 0.56 & 0.19 & $0.08 *$ & 0.22 \\
\hline V9 & 0.32 & 0.29 & 0.27 & 0.18 & 0.40 & 0.43 & 0.49 & 0.52 & 0.11 & $0.00^{* * *}$ & $0.00^{* * *}$ & $0.00^{* * *}$ \\
\hline V10 & 0.02 & 0.20 & -0.36 & -0.57 & 0.04 & 0.31 & 0.08 & -0.10 & $0.03^{* *}$ & 0.12 & $0.00^{* * *}$ & $0.00^{* * *}$ \\
\hline
\end{tabular}

*** Significant at the $1 \%$ level; ** Significant at the $5 \%$ level; ${ }^{*}$ Significant at the $10 \%$ level. T-test values measured through the p-values. (a) Variables are: V1. Shareholders' financial resources;

V2. Lenders' financial resources I; V3. Lenders' financial resources II; V4. Workers' salaries as a distribution of financial resources; V5. Customers' financial resources; V6. Customers' financial resources I;

V7. Customers' financial resources II; V8. Suppliers' financial resources; V9. Liquidity; and, V10. Profitability. 


\section{Results}

Regarding the question "Which are the most relevant SME stakeholders in order to successfully overcome a critical situation?", the classification tree revealed that the future and long-term sustainability of the firm does indeed depend on its relationship with its stakeholders. Furthermore, its results also enable us to propose a categorization of stakeholders according to their relative impact on the firm. One classification tree was obtained for each year under study, and in each case, different discriminating variables were shown to be more relevant (see Figures 2-5). Each tree can be interpreted as a set of decision rules, one for each leaf node (marked with orange squares). Regarding the financial and economic characteristics of the firm, those with collection times from customers (V7) longer than 78 days had a greater likelihood of failure, especially when they had liquidity levels (V9) below $11.5 \%$. However, firms with shorter collection times could also fail if they have liquidity levels below $10.5 \%$ and the cost of workers' salaries is more than seven times the sectoral average (V4), or if the increase in their sales income is less than 13.5 times the change for their sector. Additionally, firms with collection times of less than 78 days and liquidity greater than $10.5 \%$ have a greater likelihood of distress if financial support from suppliers (V8) is lower than $68.5 \%$. Consequently, the results show the point in the financial distress period at which each stakeholder affects the SME's outcomes and, thus, long-term sustainability.

The classification tree for $\mathrm{t}-3$ (Figure 3) can be interpreted as follows: SMEs with payment collection times of over 80 days had a greater likelihood of failure, even if their financial cost was lower than $4.5 \%$ and their sales income showed a negative trend compared with the sector average. According to the results, when the firm's debt costs were above $4.5 \%$ (V3), they had a greater likelihood of failure. However, even if the firm had a financial cost above $5.5 \%$, if its liquidity (V9) was above $6.5 \%$, it could still be a healthy firm. On the other hand, the firm could still face financial problems with a cost of financial resources of below $4.5 \%$, if customer payment collection times (V7) exceeded 80 days and the customers' economic support (V5) was greater than $70.5 \%$.

In t-2 (Figure 4), firms with liquidity lower than $9.5 \%$ were classified as failed. Additionally, if the liquidity was greater than $9.5 \%$ and the cost of financial resources was greater than $4.5 \%$, the firm was classified as failed. According to the results, in the year prior to business failure (t-1), when the firm registered profitability lower than $-3.5 \%$, liquidity lower than $4.5 \%$, and a level of credit to customers above the sectoral average (V5), it was classified as failed. The relevance of stakeholders in this case was residual.

From a financial point of view, four years before business failure ( $t-4)$, customers, workers, and suppliers appeared to be the most important factors distinguishing between distressed and non-distressed SMEs (see Table 3). In fact, those firms showing longer collection times for customer credit (customers' financial resources II), higher workforce costs, and lower levels of financial support from suppliers are more likely to fail, especially when they have less liquidity.

Problems related to commercial debt collection and customer creditworthiness appear to be the most important factors in the distress and long-term sustainability of SMEs. According to the results, hypotheses H3 (workers) and H5 (suppliers) are accepted, while H4 (customers) is rejected (see Figure 2). This is not surprising, given the problems SMEs have in accessing external funds. This finding is consistent with the idea of an optimal trade credit policy [103], according to which firms should identify the maximum amount of credit they can offer to customers without endangering their survival in the event of payment problems.

Additionally, the results indicate that those firms with greater labor force costs or lower productivity are more likely to fail. Thus, we can corroborate H3 (workers). 


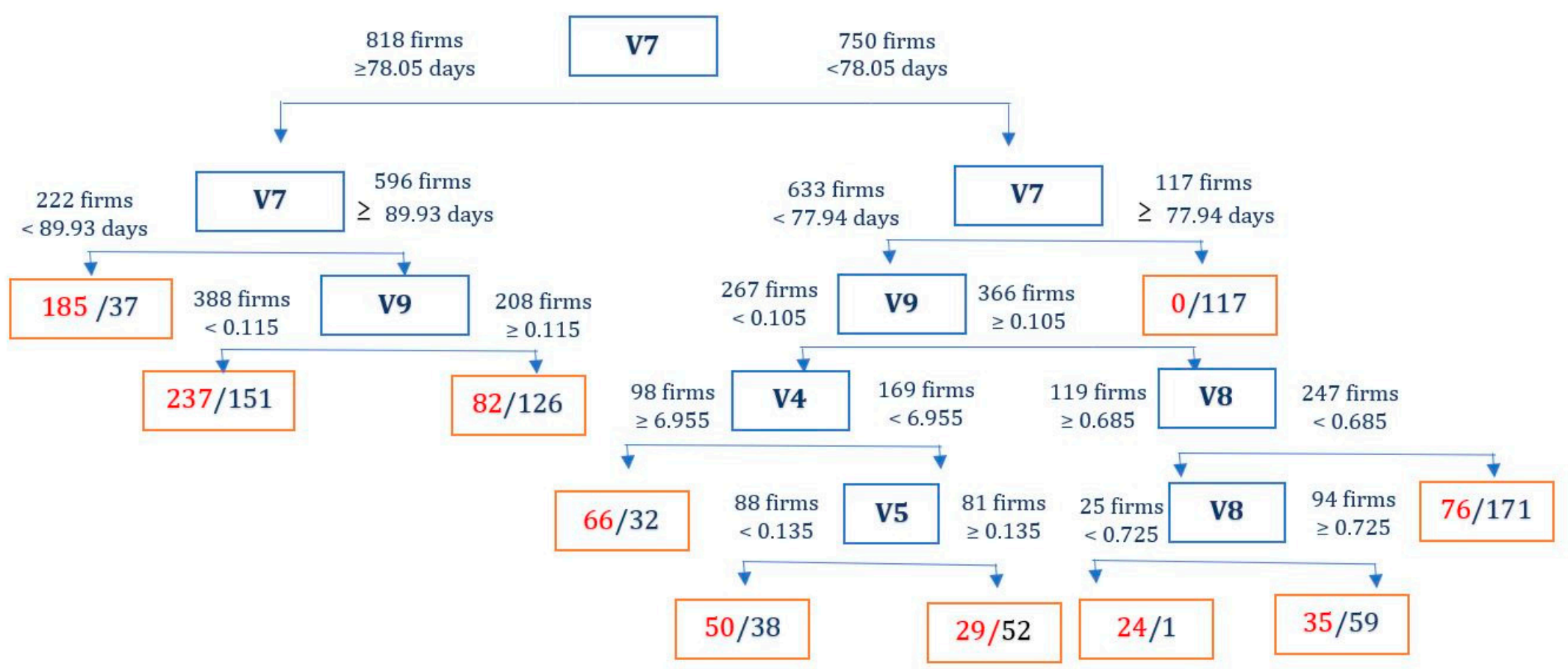

Figure 2. Classification tree (t-4). Variables are: V1. Shareholders' financial resources; V2. Lenders' financial resources I; V3. Lenders' financial resources II; V4. Workers' salaries as a distribution of financial resources; V5. Customers' financial resources; V6. Customers' financial resources I; V7. Customers' financial resources II; V8. Suppliers' financial resources; V9. Liquidity; and, V10. Profitability. 


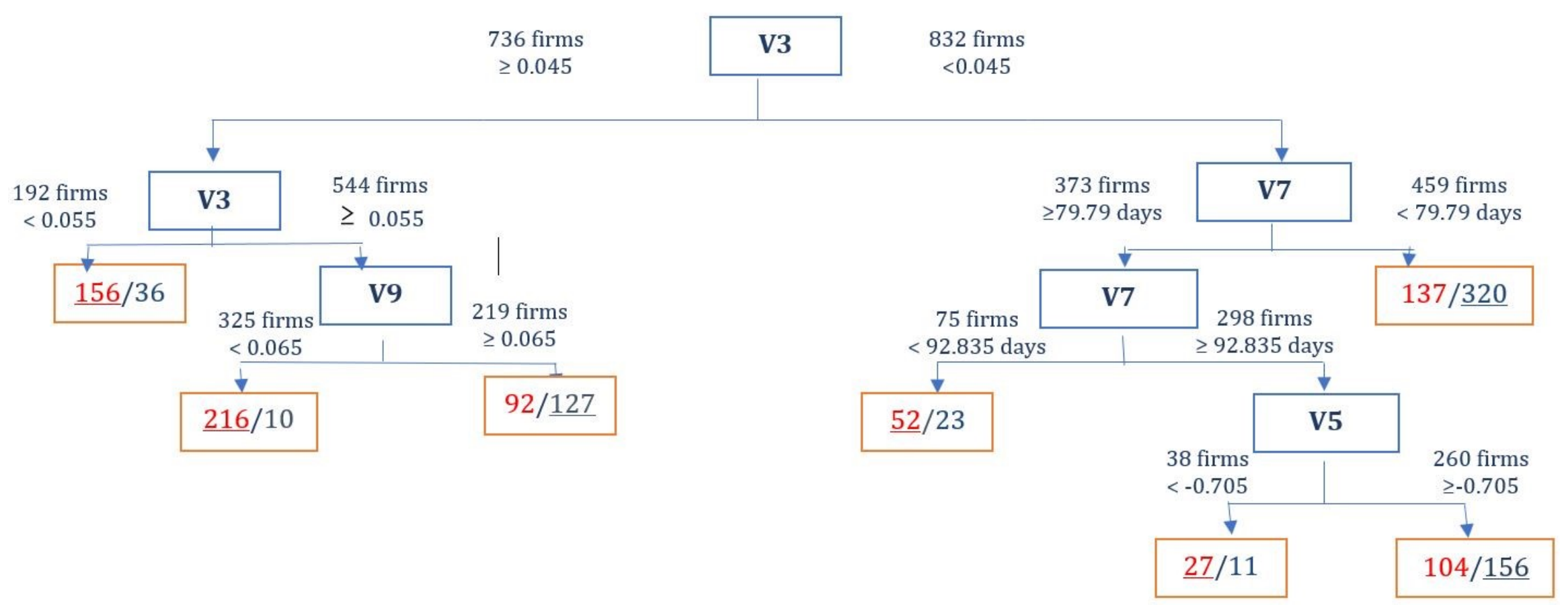

Figure 3. Classification tree (t-3). Variables are: V1. Shareholders' financial resources; V2. Lenders' financial resources I; V3. Lenders' financial resources II; V4. Workers' salaries as a distribution of financial resources; V5. Customers' financial resources; V6. Customers' financial resources I; V7. Customers' financial resources II; V8. Suppliers' financial resources; V9. Liquidity; and, V10. Profitability. 


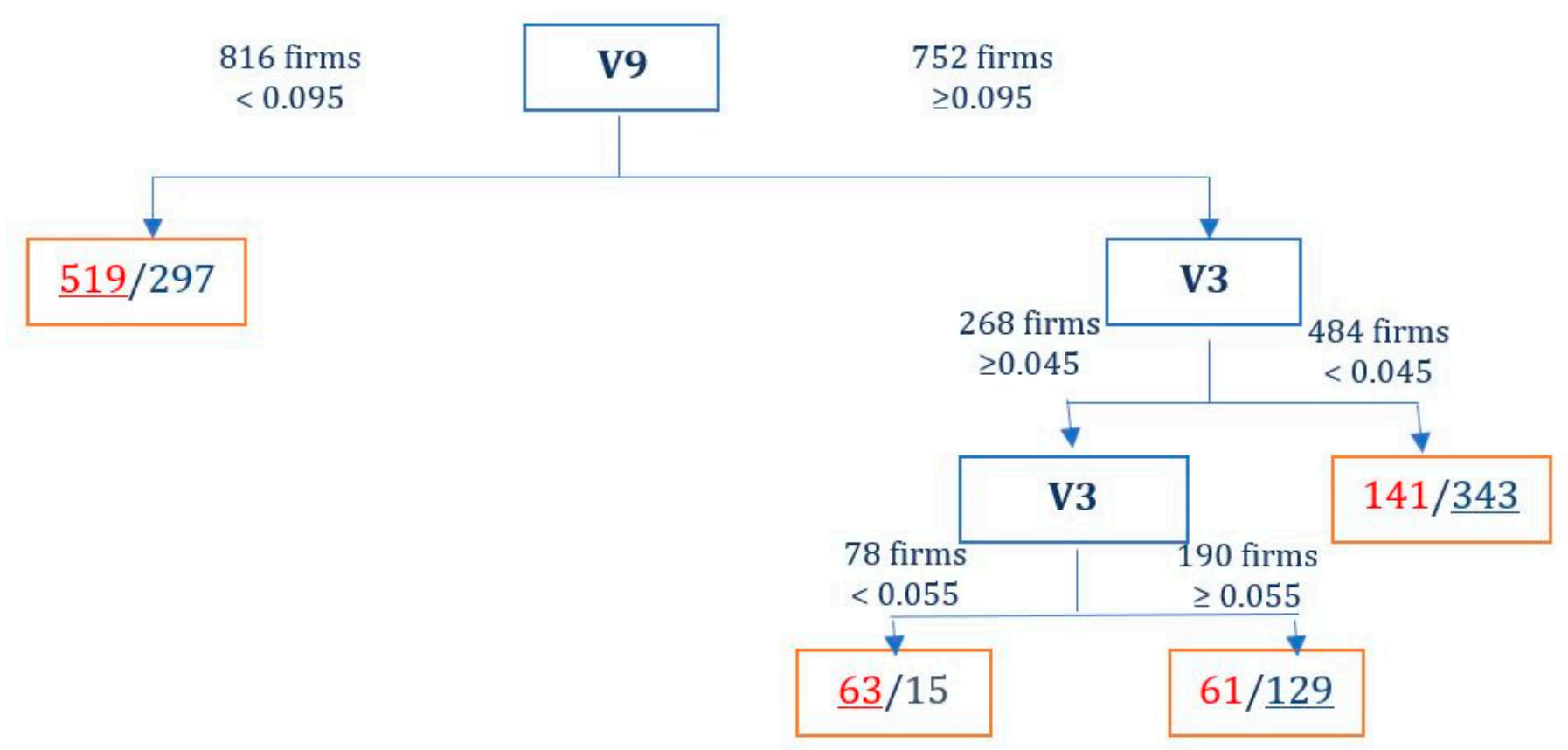

Figure 4. Classification tree (t-2). Variables are: V1. Shareholders' financial resources; V2. Lenders' financial resources I; V3. Lenders' financial resources II; V4. Workers' salaries as a distribution of financial resources; V5. Customers' financial resources; V6. Customers' financial resources I; V7. Customers' financial resources II; V8. Suppliers' financial resources; V9. Liquidity; and, V10. Profitability. 


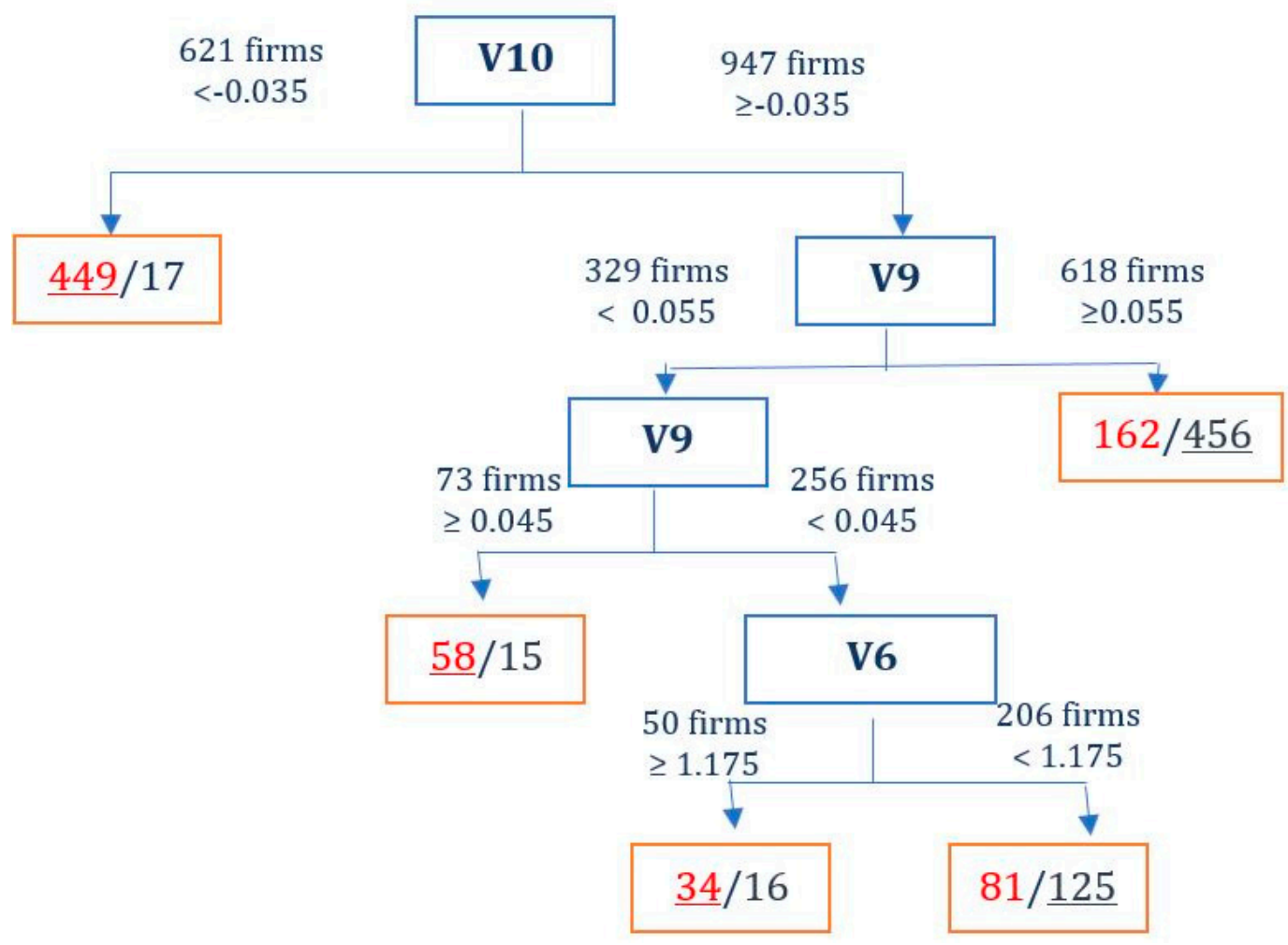

Figure 5. Classification tree (t-1). Variables are: V1. Shareholders' financial resources; V2. Lenders' financial resources I; V3. Lenders' financial resources II; V4. Workers' salaries as a distribution of financial resources; V5. Customers' financial resources; V6. Customers' financial resources I; V7. Customers' financial resources II; V8. Suppliers' financial resources; V9. Liquidity; and, V10. Profitability. 
Table 3. Variable importance in the tree models ${ }^{(a)}$.

\begin{tabular}{ccccc}
\hline Variables $^{(\mathbf{b})}$ & $\mathbf{t}-\mathbf{4}$ & $\mathbf{t}-\mathbf{3}$ & $\mathbf{t}-\mathbf{2}$ & $\mathbf{t}-\mathbf{1}$ \\
\hline V1 & & & & \\
V2 & & & & \\
V3 & & 58.900 & 36.582 & \\
V4 & 3.212 & & & \\
V5 & 2.273 & 5.846 & & \\
V6 & & & & 4.345 \\
V7 & 69.258 & 20.947 & & \\
V8 & 11.789 & & & \\
V9 & 13.468 & 14.306 & 63.418 & 28.497 \\
V10 & & & & 67.157 \\
\hline
\end{tabular}

(a) The measure of importance in rpart for each variable takes into account the reduction of impurity in splits where the variable in question represents the best split, but also those splits where it is a surrogate variable (not the selected one). In the latter case, this reduction of impurity is weighted by the adjusted agreement. The values of all variables are scaled to 100 and rounded up [95].; (b) Variables are: V1. Shareholders' financial resources; V2. Lenders' financial resources I; V3. Lenders' financial resources II; V4. Workers' salaries as a distribution of financial resources; V5. Customers' financial resources; V6. Customers' financial resources I; V7. Customers' financial resources II; V8. Suppliers' financial resources; V9. Liquidity; and, V10. Profitability.

Regarding suppliers' resources, the volume of loans from suppliers was negatively related to the likelihood of financial distress, and thus H5 (suppliers) was accepted. This again suggests that liquidity and financial problems are the most important factors in preventing the financial distress of SMEs and achieving the long-term sustainability of the firm.

In short, a lack of financial flexibility, strong dependence on commercial credit and high labor costs are the most relevant issues for $\mathrm{t}-4$ before the failure of the firm. Consequently, at this point, the most relevant stakeholder explanatory variables when it comes to overcoming a crisis and achieving long-term sustainability relate to customers, suppliers, and workers. These results are consistent with stakeholder theory and the VSA approach, providing empirical evidence on the dynamic relational aspects affecting the long-term sustainability of the firm. Therefore, our results support the idea that individual-level actions have an impact on firm outcomes in a crisis; firms should thus be viewed as a system in order to achieve long-term survival. In this sense, long-term sustainability is only possible if all the relevant actors' expectations and interests are taken into consideration. Indeed, in line with the premises of VSA, a collaborative approach is essential for long-term firm survival.

However, as expected, we saw a change in the significant stakeholders three years, two years, and one year before business failure, corroborating H6 (all stakeholders) (see Figure 6). In fact, three years before business failure, lenders and customers play the most relevant role in preventing distress and achieving the long-term sustainability of the firm (see Table 3). When considering the data for $\mathrm{t}-3$, lenders' financial resources II was the most relevant variable in the model. Again, this is not surprising, given that SMEs in such situations would probably have to borrow significant sums from financial institutions, or increase the use of payment instruments such as commercial paper to cover their lack of liquidity. Accordingly, H2 (lenders) is corroborated. Additionally, customers appear to play an important role in the SME distress in this period ( $t-3)$, since distressed SMEs have longer collection times for customer debt (customers' financial resources II). This is not consistent with our H4 (customers). In summary, lenders become relevant in the face of more serious liquidity problems. This is due to the fact that the costs of financing increase as the chances of long-term sustainability diminish.

Two years before failure ( $t-2)$, liquidity and the role of lenders' financial resources II are the two most relevant factors in distinguishing between distressed and non-distressed firms. The higher the interest rates or financial cost, the greater the likelihood of financial distress for SMEs in the year $\mathrm{t}-2$ (see Table 3). Thus, we accept H2 (lenders). 


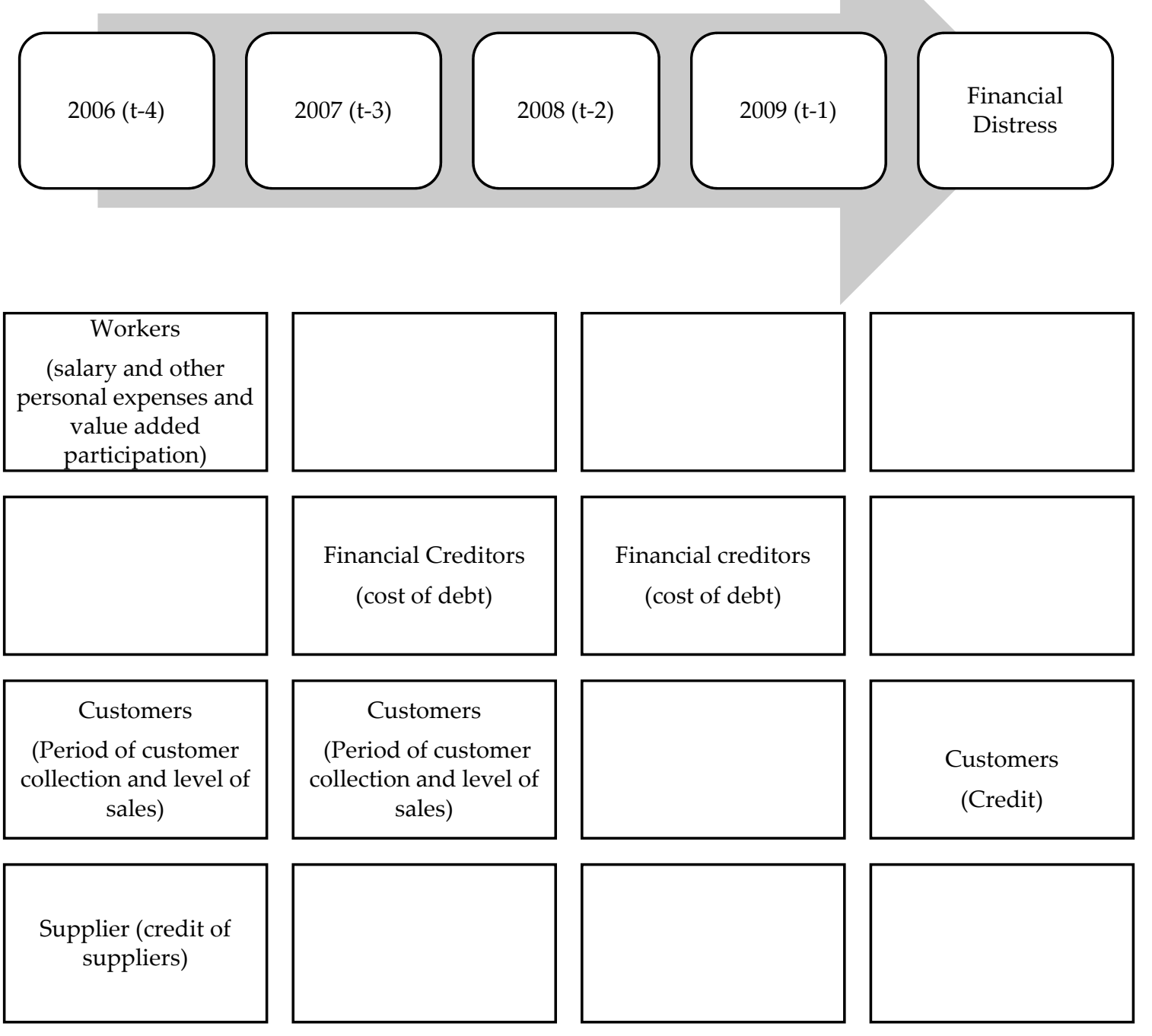

Figure 6. Stakeholders and the business failure process.

In $\mathrm{t}-1$, the profitability and liquidity of the firm are the most relevant elements (see Table 3). High levels of credit to customers (customers' financial resources I) added to a lack of profitability and liquidity problems appear to have an impact on the likelihood of business failure. Customers may hold off on making payments if they expect the firm to go under. These results suggest that stakeholders have an economic and financial influence on the likelihood of SME failure; moreover, the longer the time before business failure (t-4), the stronger the influence.

Regarding hypothesis H1 (shareholders), the findings do not support the prediction that shareholders' financial resources have a relative importance in the tree models in all years before failure. Although previous literature indicates that internal financial resources (slacks) have a positive impact on preventing business failure, our results are not in line with these findings, as our statistical tests have not found this relationship to be significant. Thus, we cannot corroborate hypothesis H1 (shareholders).

Finally, regarding H6 (all stakeholders), which suggests that, in terms of the likelihood of SME failure, stakeholder salience changes over the period leading up to business failure, our findings are in line with previous business failures studies [38]. Therefore, H6 (all stakeholders) is confirmed. 
Summing up, one and two years before business failure, the most important variables are liquidity and profitability, but we should not overlook the contribution of customers' financial resources I in the year immediately prior to firm failure. In addition, lenders' financial resources II is influential two years before firm failure. The latter is also the most important variable in $\mathrm{t}-3$, followed by customers' financial resources II. Customers' financial resources II is also the most important variable four years before business failure. It should be emphasized that the results three and four years before failure show that good management of the stakeholders (lenders, workers, and suppliers) can help the economic and financial health of the company in the medium-to-long term and, thus contribute to its long-term sustainability.

These results show that different actors have greater influence in certain years before business failure. Thus, when the firm is viewed as a system, it can be seen that achieving long-term sustainability requires an exploration of the dynamic nature of the possible pathways and processes for aligning different stakeholders' interests and needs in order to ensure collaborative action.

\section{Further Analysis}

In order to check the robustness of our results, a number of additional analyses were performed. According to the business failure literature, the characteristics of the sample could influence the results [40]. In order to demonstrate the robustness of our results, we applied the models to a test sample of 784 firms (see Table 4). This provided us with a better estimation of the generalization error, because the training error is usually an underestimate. Moreover, we could check for the presence of overfitting, when we obtained very good results in the training set, but quite poor ones with new observations. The results were similar, although the error was slightly higher, which is consistent with previous studies on business failure [104]. Overall, these results show that the variables chosen as the most significant factors in distinguishing between failed and non-failed firms provided acceptable levels of accuracy, even for different samples. The results are, therefore, robust for different samples.

Table 4. Further analyses.

\begin{tabular}{|c|c|c|c|c|c|c|c|c|}
\hline \multicolumn{9}{|l|}{ Panel A. Total Error ${ }^{(a)}$} \\
\hline \multicolumn{9}{|c|}{ Training sample } \\
\hline & \multicolumn{2}{|c|}{$\mathrm{t}-4$} & \multicolumn{2}{|c|}{$t-3$} & \multicolumn{2}{|c|}{$\mathrm{t}-2$} & \multicolumn{2}{|c|}{$\mathrm{t}-1$} \\
\hline Stakeholders' variable models & \multicolumn{2}{|c|}{$30.67 \%$} & \multicolumn{2}{|c|}{$32.65 \%$} & \multicolumn{2}{|c|}{$32.78 \%$} & \multicolumn{2}{|c|}{$28.44 \%$} \\
\hline Control variable models & \multicolumn{2}{|c|}{$38.78 \%$} & \multicolumn{2}{|c|}{$40.63 \%$} & \multicolumn{2}{|c|}{$35.84 \%$} & \multicolumn{2}{|c|}{$28.38 \%$} \\
\hline \multicolumn{9}{|c|}{ Test sample } \\
\hline & \multicolumn{2}{|c|}{$\mathrm{t}-4$} & \multicolumn{2}{|c|}{$\mathrm{t}-3$} & \multicolumn{2}{|c|}{$\mathrm{t}-2$} & \multicolumn{2}{|c|}{$\mathrm{t}-1$} \\
\hline Stakeholders' variable models & \multicolumn{2}{|c|}{$37.37 \%$} & \multicolumn{2}{|c|}{$36.22 \%$} & \multicolumn{2}{|c|}{$34.05 \%$} & \multicolumn{2}{|c|}{$28.57 \%$} \\
\hline Control variable models & \multicolumn{2}{|c|}{$41.45 \%$} & \multicolumn{2}{|c|}{$37.88 \%$} & \multicolumn{2}{|c|}{$34.82 \%$} & \multicolumn{2}{|c|}{$29.97 \%$} \\
\hline \multicolumn{9}{|l|}{ Panel B. Error Type I and II ${ }^{(b)}$} \\
\hline \multicolumn{9}{|c|}{ Training sample } \\
\hline & \multicolumn{2}{|c|}{$\mathrm{t}-4$} & \multicolumn{2}{|c|}{$t-3$} & \multicolumn{2}{|c|}{$\mathrm{t}-2$} & \multicolumn{2}{|c|}{$\mathrm{t}-1$} \\
\hline & $\begin{array}{l}\text { Type I } \\
\text { error }\end{array}$ & $\begin{array}{l}\text { Type II } \\
\text { error }\end{array}$ & $\begin{array}{l}\text { Type I } \\
\text { error }\end{array}$ & $\begin{array}{l}\text { Type II } \\
\text { error I }\end{array}$ & $\begin{array}{l}\text { Type I } \\
\text { error }\end{array}$ & $\begin{array}{l}\text { Type II } \\
\text { error }\end{array}$ & $\begin{array}{l}\text { Type I } \\
\text { error }\end{array}$ & $\begin{array}{c}\text { Type II } \\
\text { error }\end{array}$ \\
\hline Stakeholders' variable models & $33.04 \%$ & $28.31 \%$ & $22.83 \%$ & $42.48 \%$ & $39.79 \%$ & $25.76 \%$ & $25.89 \%$ & $30.99 \%$ \\
\hline Control variable models & $40.43 \%$ & $37.11 \%$ & $40.81 \%$ & $40.43 \%$ & $35.88 \%$ & $33.80 \%$ & $19.64 \%$ & $37.12 \%$ \\
\hline \multicolumn{9}{|c|}{ Test sample } \\
\hline & \multicolumn{2}{|c|}{$\mathrm{t}-4$} & & & & & & \\
\hline & $\begin{array}{l}\text { Type I } \\
\text { error }\end{array}$ & $\begin{array}{l}\text { Type II } \\
\text { error }\end{array}$ & $\begin{array}{l}\text { Type I } \\
\text { error }\end{array}$ & $\begin{array}{l}\text { Type II } \\
\text { error }\end{array}$ & $\begin{array}{l}\text { Type I } \\
\text { error }\end{array}$ & $\begin{array}{l}\text { Type II } \\
\text { error }\end{array}$ & $\begin{array}{l}\text { Type I } \\
\text { error }\end{array}$ & $\begin{array}{c}\text { Type II } \\
\text { error }\end{array}$ \\
\hline Stakeholders' variable models & $39.29 \%$ & $35.45 \%$ & $29.08 \%$ & $43.37 \%$ & $43.62 \%$ & $24.49 \%$ & $23.72 \%$ & $33.42 \%$ \\
\hline Control variable models & $45.66 \%$ & $37.25 \%$ & $39.03 \%$ & $36.73 \%$ & $40.05 \%$ & $29.59 \%$ & $19.39 \%$ & $40.56 \%$ \\
\hline
\end{tabular}

(a) Total error: misclassification of firms; (b) Type I error: classification as a non-distressed firm when it is a distressed firm; type II error: classification as distressed firm when it is a non-distressed firm. 
We also ran other models excluding the variables that represent stakeholder behavior. The level of error was greater than the model with explanatory variables capturing stakeholder behavior (see Table 4), showing that they improve the results. Accordingly, it can be seen that the stakeholder-related variables help to predict business failure. For instance, in $\mathrm{t}-4$, the total error in the training set decreased from $38.78 \%$ to $30.67 \%$ when we introduced the stakeholder variables, whereas in the test set, the equivalent reduction was from $41.45 \%$ to $37.37 \%$. More specifically, distinguishing between type I and type II errors, $45.66 \%$ (39.29\%) of distressed firms were classified as non-distressed firms and $37.25 \%$ (35.45\%) of non-distressed firms were classified as distressed firms in the control variable models and the whole model, respectively. The rest of the years can be interpreted in the same way. This analysis suggests that our results are robust to different specifications.

\section{Discussion and Conclusions}

This paper has empirically tested the influence exerted by stakeholders' control over the firm's financial resources on the likelihood of business failure. Extending previous literature on stakeholders, resource dependence theories [105], and sustainability [4,7], the study provides empirical evidence with a particular focus on SMEs and stakeholder influence on firm outcomes. As SMEs face resource constraints [106], they would benefit from an in-depth understanding of which stakeholder-related decisions could have the greatest impact on their future. In this sense, our results support the notion that a firm's capacity to generate sustainable wealth over time is determined by its relationships with its critical stakeholders. In this regard, firms that can shape their financial strategies according to stakeholder behavior may be better able to overcome critical situations and ensure their future survival.

The paper makes a number of significant contributions to the literature. First, it provides empirical evidence on the impact of individual-level actions on firm outcomes in critical situations. Accordingly, we posit that the firm should be considered as a system with dynamic relationships among numerous different actors, requiring new tools to manage and create pathways that can align their individual expectations and needs in order to achieve long-term sustainability. This is consistent with the proposals of stakeholder theory and VSA regarding sustainability.

Second, this study provides empirical evidence about which stakeholders influence the likelihood of the firms' survival, and how and when they do so, proposing a categorization of these stakeholders according to their control over firms' financial resources [88]. According to our results, the main stakeholder-related factor affecting the likelihood of financial distress of SMEs is the collection period for customer payments. This finding lends support to those studies, which point to poor credit management practices as a main cause of the failure of SMEs. Our study extends this evidence, concluding that this influence is significant for a number of years before firm failure. Accordingly, customer management is essential for SMEs to create suitable conditions for facing difficult situations in the future. However, we did not find evidence to support the significance of slacks (shareholders' impact) or external financial resources (lenders' impact).

Regarding the notion of stakeholder salience proposed by Sen and Cowley [107], we found that the dominant stakeholders when it came to preventing SME failure were employees, customers, and suppliers. This is consistent with the model of business failure that found working capital to be relevant to the survival of small firms $[14,15]$. However, our study found that the relative significance of each stakeholder depends on the stage of the business failure process, supporting some authors' claims for business failure to be viewed as a process rather than as a specific point in time [38]. This perspective is consistent with the view that critical relationships have an impact on long-term sustainability. For example, if customers are offered more credit and longer collection periods, it may negatively influence the firm's financial position. Moreover, the Spanish bankruptcy process tends to be protracted and it is often hard to recover credit provided to customers because Spanish law prioritizes secured credits, usually provided by banks. Accordingly, the problem with stimulating sales by increasing customer credit and extending the collection period persists over time, reducing the likelihood of the survival of SMEs. 
Third, our results contribute to the literature on business failure processes [38,39] by providing empirical evidence that variables related to the operating cycle (mainly linked to the cost of the workforce, supplier debt, and customer payment collection period) can predict the risk of SME failure. These variables are followed by financial issues; since the firm cannot meet its current obligations, other creditors (financial institutions) become relevant.

In addition, the study also contributes to the business failure prediction models by showing that although trade credit is significant in preventing SMEs' financial distress, the financial recovery of those firms also depends on the availability of financial resources from banks. That is, trade credit was also found to be significant in predicting the likelihood of SME financial distress; interestingly, the role of trade credit is only significant in the first stage of SMEs' business failure process (t-4). We suggest that although trade credit makes up the largest share of firms' liabilities, SMEs' distress is more closely related to the cost of debt than the cost of trade credit. In fact, we also show that the cost of debt is the second most important obstacle to the survival of SMEs. This indicates that when SMEs attempt to access new debt, financial institutions tighten credit conditions which increases the SMEs' risk of failure. That is, SMEs incur excessive refinancing costs [57], meaning that lenders play a relevant role when the firm is closer to failure ( $t-3 ; \mathrm{t}-2)$. Consequently, the results reveal dynamic relationships with stakeholders that change over time. This is consistent with the dynamic nature of organizational relationships highlighted by business sustainability studies [4]. Thus, cooperation has a significant influence and taking a long-term perspective about stakeholder relationships can help to ensure the sustainability of the firm.

Regarding methodological contributions, as far as we know, this paper is the first in the business failure literature to analyze the relationship between business failure and SME stakeholders by means of classification trees [88]. Thus, this study provides a guide to firm management and public institutions seeking to prioritize actions based on the relative importance of stakeholders' role in the SMEs' risk of failure.

This study has several practical implications. First, managers of SMEs can make use of the results by incorporating a stakeholder perspective when making strategic and financial decisions, taking into consideration which of them could be more significant at a specific point of time. Consequently, if the SME management better understands its stakeholders and can handle them strategically, there is a lower risk of business failure. Second, government agencies and institutions could introduce policies that address the impact of stakeholders on the likelihood of business failure, thus potentially enabling the recovery of viable enterprises facing severe financial crises. In this sense, failing SMEs could reorganize if they anticipate in advance the factors that contribute to an increasing risk of bankruptcy. Third, our study also contributes to the literature by providing an empirical examination in a context of crisis. This context is especially relevant due to the cooperation required between stakeholders to ensure the survival of the firm in such circumstances.

Despite the contributions made, this study has several limitations, which represent opportunities for future research. This paper only used financial explanatory variables relating to the stakeholders' power. As such, extending the models with qualitative variables could help provide a better understanding of stakeholder behavior. In addition, the sample was matched on the basis of industry and firm size. Additional samples matched by the location and the age of the firm could also offer interesting new results. Furthermore, since the period under study was fairly short, the relative importance of different macroeconomic circumstances was not analyzed. Using other samples from different periods would allow an assessment of the influence of macroeconomic conditions. In this regard, it could be interesting to carry out similar research into the period following the global financial crisis, in order to observe possible differences in stakeholder behavior in that economic climate.

Author Contributions: M.M.-L. Conceptualization, formal analysis, investigation, project administration and methodology; E.A.-C. Software, data curation, methodology, visualization and funding acquisition; A.M.P.d.l.C. Validation, resources, writing-original draft preparation, writing-review and editing and supervision. 
Funding: This research was partially funded by the European Regional Development Fund of the European Union, belonging to the research group: Sistemas de información externa e interna de las organizaciones: información corporativa y para la gestión (GISEIO). This research was also partially funded by the Universidad de Castilla-La Mancha, grant number 2019-GRIN-26906.

Acknowledgments: The authors would like to thank the two anonymous reviewers and the editor for their observations and help during the revision process.

Conflicts of Interest: The authors declare no conflict of interest.

\section{References}

1. Rodriguez, M.A.; Ricart, J.E.; Sanchez, P. Sustainable Development and the Sustainability of Competitive Advantages: A Dynamic and Sustainable View of the Firm. Sustain. Dev. Compet. Advant. 2002, 11, 135-146. [CrossRef]

2. Stubbs, W.; Cocklin, C. Conceptualizing a "Sustainability Business Model”. Organ. Environ. 2008, 21, $103-127$. [CrossRef]

3. Tencati, A.; Perrini, F. The sustainability perspective: A new governance model. In Corporate Social Responsibility. Reconciling Aspiration with Application; Kakabadse, A., Morsing, M., Eds.; Palgrave Macmillan: London, UK, 2006; pp. 94-111.

4. Caputo, F.; Buhnova, B.; Walletzky, L. Investigating the role of smartness for sustainability: Insights from the Smart Grid domain. Sustain. Sci. 2018, 13, 1299-1309. [CrossRef]

5. AccountAbility. AccountAbility 1000 (AA1000) Framework. Standard, Guidelines and Professional Qualification; ISEA: London, UK, 1999.

6. Post, J.E.; Preston, L.E.; Sachs, S. Managing the extended enterprise: The new stakeholder view. Calif. Manag. Rev. 2002, 45, 5-27. [CrossRef]

7. Saviano, M.; Caputo, F. Managerial choices between systems, knowledge and viability. In Contributions to Theoretical and Practical Advances in Management. A Viable Systems Approach (VSA); Barile, S., Ed.; Aracne: Roma, Italy, 2013; pp. 219-242.

8. Del Giudice, M.; Khan, Z.; De Silva, M.; Scuotto, V.; Caputo, F.; Carayannis, E. The micro-level actions undertaken by owner-managers in improving the sustainability practices of cultural and creative small and medium Enterprises: A United Kingdom-Italy comparison. J. Organ. Behav. 2017, 38, 1396-1414. [CrossRef]

9. Pojasek, R.B. A framework for business sustainability. Environ. Qual. Manag. 2007, 17, 81-88. [CrossRef]

10. Box, M. The death of firms: Exploring the effects of environment and birth cohort on firm survival in Sweden. Small Bus. Econ. 2008, 31, 379-393. [CrossRef]

11. Organisation for Economic Co-Operation and Development. The Impact of the Global Crisis on SME and Entrepreneurship Financing and Policy Responses. 2009. Available online: http://www.oecd.org/cfe/smes/ 43183090.pdf (accessed on 3 March 2018).

12. European Commission. A Partial and Fragile Recovery. Annual Report on European SMEs 2013/2014. Available online: http://ec.europa.eu/enterprise/policies/sme/facts-figures-analysis/performance-review/files/ supporting-documents/2014/annual-report-smes-2014_en.pdf (accessed on 10 April 2018).

13. Mitroff, I.I.; Pearson, C.M.; Harrington, L.K. The Essential Guide to Managing Corporate Crises; Oxford University Press: New York, NY, USA, 1996.

14. Altman, E.I. Financial ratios, discriminant analysis and the prediction of corporate bankruptcy. J. Financ. 1968, 23, 589-609. [CrossRef]

15. Ohlson, J.A. Financial ratios and the probabilistic prediction of bankruptcy. J. Account. Res. 1980, 18, $109-131$. [CrossRef]

16. Platt, H.D.; Platt, M.B. Development of a class of stable predictive variables: The case of bankruptcy prediction. J. Bus. Financ. Account. 1990, 17, 31-51. [CrossRef]

17. Lee, D.Y.; Tsang, E.W.K. The effects of entrepreneurial personality, background and network activities on venture growth. J. Manag. Stud. 2001, 38, 583-602. [CrossRef]

18. Schutjens, V.A.; Wever, E. Determinants of new firm success. Pap. Reg. Sci. 2000, 79, 135-153. [CrossRef]

19. Brixy, U.; Grotz, R. Regional patterns and determinants of birth and survival of new firms in western Germany. Entrep. Reg. Dev. 2007, 19, 293-312. [CrossRef] 
20. Everett, J.; Watson, J. Small business failure and external risk factors. Small Bus. Econ. 1998, 11, 371-390. [CrossRef]

21. Carter, R.; Van Auken, H. Small firm bankruptcy. J. Small Bus. Manag. 2006, 44, 493-512. [CrossRef]

22. Schlierer, H.; Werner, A.; Signori, S.; Garriga, E. How do European AME owner-managers make sense of "Stakeholder Management"? Insights from a cross-national study. J. Bus. Ethics 2012, 109, 39-51. [CrossRef]

23. Mutezo, A. Credit rationing and risk management for SMES: The way forward for South Africa. Corp. Ownersh. Control 2013, 10, 153-163. [CrossRef]

24. Fraser, S.; Storey, D.; Frankish, J.; Roberts, R. The relationship between training and small business performance: An analysis of the Barclays Bank small firms training loan scheme. Environ. Plan. C Gov. Policy 2002, 20, 211-233. [CrossRef]

25. Mulling, D.; Silveira, M.; Dutra, M.; Lauren, A. Value Creation from Internationalization of Sugar Cane by-products: A multi-stakeholder view of artisanal cachaça production. Rev. Bras. Gestão Neg. 2015, 17, 890-910. [CrossRef]

26. Hill, R.; Stewart, J. Human resource development in small organizations. J. Eur. Ind. Train. 2000, $24,105-117$. [CrossRef]

27. Porter, M.E. Competitive Strategy; Free Press: New York, NY, USA, 1980.

28. Hillman, A.J.; Hitt, M.A. Corporate political strategy formulation: A model of approach, participation, and strategy decisions. Acad. Manag. Rev. 1999, 24, 825-842. [CrossRef]

29. Jenkins, H. Small business champions for corporate social responsibility. J. Bus. Ethics 2006, 67, 241-256. [CrossRef]

30. James, S. Strategic bankruptcy: A stakeholder management perspective. J. Bus. Res. 2016, 69, 492-499. [CrossRef]

31. Pajunen, K. Stakeholders Influences in Organizational Survival. J. Manag. Stud. 2006, 43, 1261-1288. [CrossRef]

32. Altman, E.; Sabato, G. Modelling credit risk for SMEs evidence from the US market. Abacus 2007, 43, $332-356$. [CrossRef]

33. Gray, S.; Mirkovic, A.; Ragunathan, V. The determinants of credit ratings Australian evidence. Aust. J. Manag. 2006, 31, 333-353. [CrossRef]

34. Flores-Jimeno, R.; Jimeno-García, I. Dynamic analysis of different business failure process. Probl. Perspect. Manag. 2017, 15, 486-499. [CrossRef]

35. Jimeno-García, I.; Rodriguez-Merayo, M.A.; Vidal-Blasco, M.A. The failure processes and their relation to the business interruption moment. Int. J. Manag. Financ. Account. 2017, 9, 68-83. [CrossRef]

36. Laitinen, E.; Lukason, O.; Suvas, A. Are firm failure processes different? Evidence from seven countries. Investig. Manag. Financ. Innov. 2014, 11, 212-222.

37. Lukason, O.; Hoffman, R. Firm failure causes: A population level study. Probl. Perspect. Manag. 2015, 13, 45-55.

38. Lukason, O.; Laitinen, E. Firm failure processes and components of failure risk: An analysis of European bankruptcy firms. J. Bus. Res. 2019, 98, 380-390. [CrossRef]

39. Manzaneque, M.; Banegas, R.; García-Pérez-De-Lema, D. Different business failure processes. Dynamic analysis through the application of cluster analysis. Rev. Eur. Dir. Econ. Empresa 2010, 19, 67-88.

40. Ooghe, H.; Prijcker, S. Failure processes and causes of company bankruptcy: A typology. Manag. Decis. 2008, 46, 223-242. [CrossRef]

41. Mitchell, R.K.; Agle, B.R.; Wood, D.J. Toward a theory of stakeholder identification and salience: Defining the principle of who and what really counts. Acad. Manag. Rev. 1997, 22, 853-886. [CrossRef]

42. Pearson, C.M.; Clair, J.A. Reframing Crisis Management. Acad. Manag. Rev. 1998, 23, 59-77. [CrossRef]

43. Ulmer, R.R. Effective Crisis Management through Established Stakeholder Relationships. Manag. Commun. Q. 2001, 14, 590-615. [CrossRef]

44. Freeman, E. Strategic Management: A Stakeholder Approach; Pitman: Boston, MA, USA, 1984.

45. Fassin, Y. Stakeholders management, reciprocity and stakeholder responsibility. J. Bus. Ethics 2012, 109, 83-96. [CrossRef]

46. Weerawardena, J.; O'Cass, A.; Julian, C. Does industry matter? Examining the role of industry structure and organizational learning in innovation and brand performance. J. Bus. Res. 2006, 59, 37-45. [CrossRef] 
47. Becchetti, L.; Cicirettim, R.; Hasan, I.; Kobeissi, N. Corporate social responsibility and shareholder's value. J. Bus. Res. 2012, 65, 1628-1635. [CrossRef]

48. Pereira, Y.; Rossetto, C.R. Stakeholder management capability and performance in Brazilian cooperatives. Rev. Bras. Gestão Neg. 2015, 17, 870-889. [CrossRef]

49. Chatterjee, S.; Dhillon, U.S.; Ramirez, G.G. Resolution of financial distress: Debt restructuring in chapter 11, prepackaged bankruptcy, and workouts. Financ. Manag. 1996, 25, 5-18. [CrossRef]

50. Jenkins, H. A Critique of Conventional CSR Theory: An SME Perspective. J. Gen. Manag. 2004, $29,37-57$. [CrossRef]

51. Gallo, M. The family business and its social responsibilities. Fam. Bus. Rev. 2004, 17, 135-147. [CrossRef]

52. Fiegener, M.K.; Brown, B.M.; Dreux, D.R.; Dennis, W.J. The adoption of outside boards by small private US firms. Entrep. Reg. Dev. 2000, 12, 291-309. [CrossRef]

53. Ullmann, A. Data in search of a theory: A critical examination of the relationships among social performance, social disclosure, and economic performance of U.S. firms. Acad. Manag. Rev. 1985, 10, 540-557.

54. Petersen, M.A.; Rajan, R.G. The benefits of lending relationships: Evidence from small business data. J. Financ. 1994, 49, 3-38. [CrossRef]

55. Myers, S.C.; Majluf, N.S. Corporate Financing and Investment Decisions when Firms Have Information that Investors do not have. J. Financ. Econ. 1984, 13, 187-221. [CrossRef]

56. Berger, A.N.; Udell, G.F. The economics of small business finance: The roles of private equity and debt markets in the financial growth cycle. J. Bank. Financ. 1998, 22, 613-673. [CrossRef]

57. Aybar, C.; Casino, A.; López, J. La reestructuración financiera de las pymes en crisis. Endogeneidad en la Elección entre vía privada y vía concursal. Investig. Econ. 2006, 30, 137-162.

58. Bourgeois, L.J. On the measurement of organizational slack. Acad. Manag. Rev. 1981, 6, 29-39. [CrossRef]

59. George, G. Slack resources and the performance of privately held firms. Acad. Manag. J. 2005, 48, 661-676. [CrossRef]

60. Ou, C.; Haynes, G.W. Acquisition of additional equity capital by small firms-Findings from the national survey of small business finances. Small Bus. Econ. 2006, 27, 157-168. [CrossRef]

61. Coleman, S. Access to capital and terms of credit: A comparison of men and women-owned small businesses. J. Small Bus. Manag. 2000, 38, 37-52.

62. Wruck, K. Financial Distress: Reorganization and organization efficiency. J. Financ. Econ. 1990, $27,419-444$. [CrossRef]

63. Altman, E. A further investigation of the bankruptcy cost question. J. Financ. 1984, 39, 1067-1089. [CrossRef]

64. Pettit, R.R.; Singer, R.F. Small business finance: A research agenda. Financ. Manag. 1985, 14, 47-60. [CrossRef]

65. Fazzari, S.M.; Petersen, B. Working capital and fixed investment: New evidence on financing constraints. RAND J. Econ. 1993, 24, 328-342. [CrossRef]

66. Gallego, S.; García, A.; Saurina, J. The Sian and European Banking System: The Case of Spain in the Quest for Development and Stability. [Working Paper Banco de España, n. 217] Servicio de Estudios. 2002. Available online: https://ideas.repec.org/p/bde/wpaper/0217.html (accessed on 16 March 2018).

67. McEvoy, G.M. Small business personnel practices. J. Small Bus. 1984, 22, 1-8.

68. Denis, D.; Kruse, T. Managerial discipline and corporate restructuring following performance declines. J. Financ. Econ. 2000, 55, 391-424. [CrossRef]

69. Goss, D. Social Harmony and the Small Firm: A Reappraisal. Sociol. Rev. 1988, 36, 114-132. [CrossRef]

70. Becker, B.; Gerhart, G. The impact of human resource management on organizational performance: Progress and prospects. Acad. Manag. J. 1996, 39, 779-801.

71. Wang, H.-M.D.; Sengupta, S. Stakeholder relationship, brand equity, firm performance: A resource-based perspective. J. Bus. Res. 2016, 69, 5561-5568. [CrossRef]

72. Ruf, B.M.; Muralidhar, K.; Brown, R.M.; Janney, J.J.; Paul, K. An empirical investigation of the relationship between change in corporate social performance and financial performance: A stakeholder theory perspective. J. Bus. Ethics 2001, 32, 143-156. [CrossRef]

73. Bird, R.; Hall, D.A.; Momenté, F.; Reggiani, F. What corporate social responsibility activities are valued by the market? J. Bus. Ethics 2007, 76, 189-206. [CrossRef]

74. Holmlund, M.; Kock, S. Buyer dominated relationships in a supply chain-A case study of four small sized suppliers. Int. Small Bus. J. 1996, 15, 26-40. [CrossRef] 
75. Khan, M.R.; Rocha, J. Recurring managerial problems in small business. Am. J. Small Bus. 1982, 7, 50-58. [CrossRef]

76. Kestens, K.; van Cauwenberge, P.; Bauwhede, H.V. Trade credit and com- pany performance during the 2008 financial crisis. Account. Financ. 2012, 52, 1125-1151. [CrossRef]

77. Martínez-Sola, C.; García-Teruel, P.-J.; Martínez-Solano, P. Trade credit and SME profitability. Small Bus. Econ. 2014, 42, 561-577. [CrossRef]

78. Meltzer, A.H. Mercantile credit, monetary policy, and size of firms. Rev. Econ. Stat. 1960, 42, $429-437$. [CrossRef]

79. Bowen, R.; Daley, L.; Huber, C. Evidence on the existence and determinants of inter-Industry leverage differences. Financ. Manag. 1982, 11, 10-20. [CrossRef]

80. Fitzgerald, T. Predicting and pre-empting the corporate heart attack. Bus. Credit 2006, 108, 68.

81. Altman, E. Corporate Financial Distress and Bankruptcy, 2nd ed.; Wiley: New York, NY, USA, 1993.

82. Gazengel, A.; Thomas, P. Les Défaillances d’Entreprises; Cahiers de Recherche, 92; École Superieure de Comerse: Paris, France, 1992.

83. Chowdhury, S.D.; Lang, J.R. Crisis, decline, and turnaround: A test of competing hypotheses for short-term performance improvement in small firms. J. Small Bus. Manag. 1993, 31, 8-17.

84. Hambrick, D.C.; D'Aveni, R.A. Large corporation failures as downward spirals. Adm. Sci. Q. 1988, 33, 1-23. [CrossRef]

85. Ross, S.A.; Westerfield, R.W.; Jaffe, J. Corporate Finance, 7th ed.; McGraw-Hill International: Singapore, 2005.

86. BOE (Official State Bulletin). Law 22/2003, Spanish Insolvency Act 22-2003. 164, 10 July; Spanish State Agency: Madrid, Spain, 2003.

87. Keasey, K.; Watson, R. Non-financial symptoms and the prediction of small company failure: A test of the Argenti hypotheses. J. Bus. Financ. Account. 1987, 14, 335-354. [CrossRef]

88. Alfaro, E.; Gámez, M.; García, N. Linear discriminant analysis versus AdaBoost for failure forecasting. Span. J. Financ. Account. 2008, 37, 13-32.

89. Richardson, F.; Kane, G.; Lobingier, P. The Impact of Recession on the Prediction of Corporate Failure. J. Bus. Financ. Account. 1998, 25, 167-186. [CrossRef]

90. Mishina, Y.; Pollock, T.G.; Porac, J.F. Are more resources always better for growth? Resource stickiness in market and product expansion. Strateg. Manag. J. 2004, 25, 1179-1197. [CrossRef]

91. Sui, S.; Baum, M. Internationalization strategy, firm resources and the survival of SMEs in the Export Market. J. Int. Bus. Stud. 2014, 45, 821-841. [CrossRef]

92. Routledge, J.; Gadenne, D. Financial distress, reorganization and corporate performance. Account. Financ. 2000, 40, 233-259. [CrossRef]

93. Steijvers, T.; Voordeckers, W.; Van Hoof, K. Collateral, relationship lending and family firms. Small Bus. Econ. 2010, 34, 243-259. [CrossRef]

94. Binks, M.R.; Ennew, C.T.; Reed, G.V. Information asymmetries and the provision of finance to small firms. Int. Small Bus. J. 1992, 11, 35-46. [CrossRef]

95. Smith, C.W.; Warner, R.L. On financial contracting: An analysis of bond covenants. J. Financ. Econ. 1979, 7, 117-161. [CrossRef]

96. Theng, L.G.; Boon, J.L.W. An exploratory study of factors affecting the failure of local small and medium enterprises. Asia Pac. J. Manag. 1996, 13, 47-61. [CrossRef]

97. Molina, C.A.; Preve, L.A. Trade receivables policy of distressed firms and its effect on the costs of financial distress. Financ. Manag. 2009, 38, 663-686. [CrossRef]

98. Von Stein, J.H.; Ziegler, W. The prognosis and surveillance of risks from commercial credit borrowers. J. Bank. Financ. 1984, 8, 249-268. [CrossRef]

99. García-Teruel, P.J.; Martínez-Solano, P. A dynamic approach to accounts receivable: A study of Spanish SMEs. Eur. Financ. Manag. 2010, 16, 400-421. [CrossRef]

100. Breiman, L.; Friedman, J.H.; Olshen, R.; Stone, C.J. Classification and Regression Trees; Wadsworth International Group: Belmont, TN, USA, 1984.

101. Therneau, T.; Atkinson, B.; Ripley, B. rpart: Recursive partitioning and regression trees. $R$ Package Version 2015, 4, 1-9.

102. R Development Core Team. R: A Language and Environment for Statistical Computing; R Foundation for Statistical Computing: Vienna, Austria, 2017. 
103. Emery, G.W. A pure financial explanation for trade credit. J. Financ. Quant. Anal. 1984, 19, $271-285$. [CrossRef]

104. Alfaro, E.; García, N.; Gámez, M.; Elizondo, D. Bankruptcy forecasting: An empirical comparison of AdaBoost and neural networks. Decis. Support Syst. 2008, 45, 110-122. [CrossRef]

105. Pfeffer, J.; Salancik, G.R. The External Control of Organizations; Harper \& Row: New York, NY, USA, 1978.

106. Jarillo, J.C. Entrepreneurship and growth: The strategic use of external resources. J. Bus. Ventur. 1989, 4, 133-147. [CrossRef]

107. Sen, S.; Cowley, J. The relevance of stakeholder theory and social capital theory in the context of CSR in SMEs: An Australian perspective. J. Bus. Ethics 2013, 118, 413-427. [CrossRef]

(C) 2019 by the authors. Licensee MDPI, Basel, Switzerland. This article is an open access article distributed under the terms and conditions of the Creative Commons Attribution (CC BY) license (http://creativecommons.org/licenses/by/4.0/). 